\title{
PENGARUH SENAM KAKI DIABETIK TERHADAP SENSITIVITAS KAKI PENDERITA DM DI PUSKESMAS PARUNGPONTENG KECAMATAN CIBALONG KABUPATEN TASIKMALAYA
}

Bayu Brahmantia', Miftahul Falah², Ida Rosidawati³, Aida sri R ${ }^{4}$, Nita Dinia F4.

'Universitas Muhammadiyah Tasikmalaya

Article Information

Received: June 12th, 2020

Revised: July 3th, 2020

Available online: July, 2020

Keywords

Senam Kaki Diabetes Melitus, Sensitivitas
Kaki
Correspondence

Phone: (+62)81323358895

E-mail: brahmantiabayu481@gmail.com
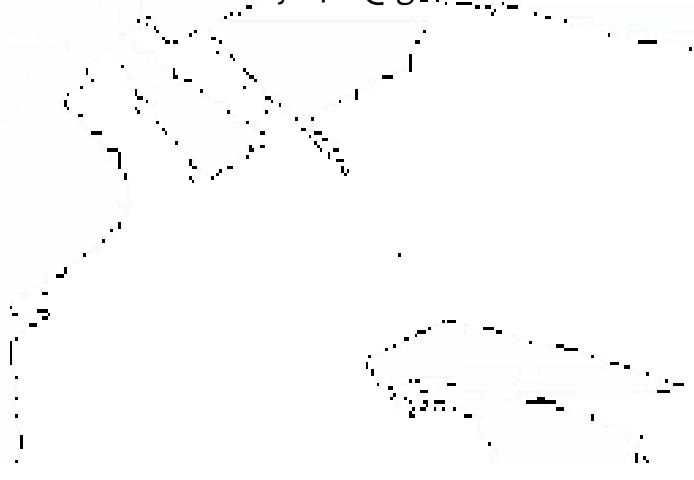

\section{PENDAHULUAN}

Diabetes melitus (DM) merupakan penyakit kronis dengan angka kematian yang tinggi di dunia. Karena penyakit DM dapat menimbulkan berbagai

\section{ABSTRACT}

Komplikasi yang sering terjadi pada pasien Diabetes Mellitus (DM) adalah menurunnya sensitivitas kaki. Perawatan kaki DM sangat penting untuk menjaga vaskularisasi, memperkuat otot kaki dan mencegah terjadinya komplikasi yang fatal. Salah satu tindakan pencegahan untuk menjaga keutuhan kulit yaitu dengan senam kaki yang diyakini dapat meningkatkan aliran darah ke daerah ektremitas sehingga dapat meningkatkan sensitivitas diektremitas. Tujuan penelitian ini untuk mengetahui pengaruh senam kaki diabetik terhadap sensitivitas kaki pada penderita DM. Jenis penelitian experimient dengan desain pre and post test. Dengan sampel 25 orang, instrument pẻnelitiah menggunakan skala sensitivitas. Alat ukur penelitian ${ }^{-}$ini mẹggunakan kapas, sikat dan jarum. analisis pehelitian mengंgunakan uji $T$ test. Senam kaki dilakukan 2 "kạli selama 1 minggu. Hasil penelitian sensitivitas kaki sẹpelum dilakukan senam kaki memiliki rata- rata sensitivitas $\overrightarrow{1,6} 7$ dan sesudah dilakukan senam kaki memiliki rata- rata sensitivitas 2,36, sensitivitas lebih baik sesudah diberikan senam kaki ( $p$ value 0,001). Maka dapat disimpulkan bahwa ada pengaruh senam kaki diabetik terhadap sensitivitas kaki pada penderita DM di Puskesmas Parungponteng Kecamatan Cibalong Kabupaten Tasikmalaya.

komplikasi pada penderitanya berupa kecacatan bahkan sampai kepada kematian. Sebagaimana yang dilaporkan oleh International Diabetes Federation (IDF) pada tahun 2013 menyatakan bahwa Indonesia 
menduduki peringkat ke-7 dunia dari 10 besar negara dengan DM tertinggi. Populasi penderita DM di Indonesia pada tahun 2013 mencapai 5,8\% atau sekitar 8,5 juta penduduk dengan rentang usia 20-79 tahun. Proporsi jumlah pasien DM di Indonesia pada tahun 2013 masih didominasi oleh kaum perempuan dengan total sebesar 4,9 juta penderita atau lebih besar daripada kaum laki- laki yakni sebesar 3,6 juta penderita (Muzahidin, Hartoyo, and Maria, 2015). Pusat data dan informasi Kemenkes RI (2012) juga mencatat bahwa DM merupakan penyakit yang masuk sepuluh besar dari daftar penyakit yang menyebabkan kematian di Indonesia setelah perdarahan intrakranial, stroke, gagal ginjal, gagal jantung, dan penyakit jantung lainnya.

Angka kejadian DM di Jawa Barat mencapai 4,2\% dengan jumlah prediabet sebesar 7,8\%. Sementara itu Riset Kesehatan Dasar Tahun 2018 menempatkan prevalensi diabetes di Indonesia di urutan ke 6 , yang berarti mengalami peningkatan cukup signifikan selama lima tahun terakhir. Di tahun 2013, angka prevalensi diabetes pada orang dewasa mencapai 6,9 \%, dan di tahun 2018 angka terus melonjak menjadi 8,5 \% (Riset Kesehatan Dasar 2018). Ini sejalan dengan data yang dilaporkan oleh dinas kesehatan kota tasikmalaya ynag menyatakan bahwa penderita DM di Tasikmalaya mencapai 323789 orang (Dinkes, 2019)

Lebih dari $50 \%$ pasien DM mengalami neuropati yang akan berkembang menjadi ulkus kaki. Resiko neuropati perifer 2 kali lebih tinggi dibanding pada pasien non diabetes. (Smeltzer \& Bare 2002). Dampak ulkus yang sudah terinfeksi dan tidak segera

\section{HASIL PENELITIAN}

Tabel 1. Sensitivitas Kaki Penderita Diabetes Mellitus Sebelum Dilakukan Senam Kaki Di Puskesmas Parungponteng Kecamatan Cibalong Kabupaten Tasikmalaya mendapatkan penanganan akan dilakukan amputasi supaya infeksi tidak menyebar ke bagian yang lainya. Ini merugikan bagi pasien karena akan menganggu aktivitas dan akan menurunkan kualitas hidup. Penanganan neuropati dapat dilakukan dengan perawatan kaki DM. Perawatan kaki merupakan upaya pencegahan primer terjadinya luka pada kaki DM. Gejala awal biasanya disertai kesemutan atau baal yang akan menyebabkan penurunan sensitivitas kaki. Salah satu tindakan yang harus dilakukan dalam perawatan kaki untuk deteksi dini adalah senam kaki diabetik (Tjokroprawiro, 2007).

Senam kaki DM merupakan kegiatan atau latihan yang dilakukan oleh pasien DM untuk membantu melancarkan peredaran darah kaki yang dapat menurunkan derajat neuropati. Senam kaki ini memiliki banyak manfaat baik bagi pasien yang mengalami neuropati maupun yang belum mengalaminya. Diantaranya dapat memperkuat otototot kecil, otot betis, dan otot paha, serta mengatasi keterbatasan gerak sendi yang sering dialami oleh yang dilakukan untuk melancarkan peredaran darah, memperkuat otot-otot kecil dan mencegah terjadinya luka pada kaki. Efek dari Senam kaki dapat mencegah terjadinya luka dan membantu melancarkan peredaran darah bagian kaki. (Prima, 2019).

\section{METODOLOGI PENELITIAN}

Jenis Penelitian ini adalah quasi eksperimen dengan desain pre dan post test, pengambilan sampel dengan cara total sampling, jumlah sampel 25 orang, instrument penelitian menggunakan skala sensitivitas. penderita DM. Senam kaki diabetik adalah kegiatan 


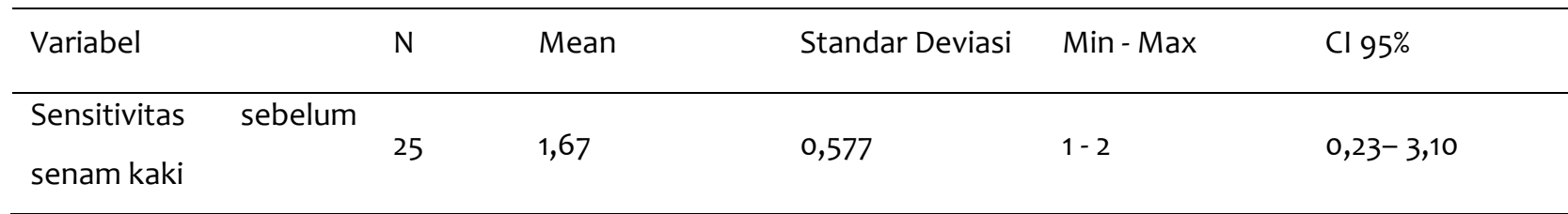

Sumber: Data Penelitian, 2019

Berdasarkan tabel diketahui bahwa dari 25 orang

sensitivitas terendah dan tertinggi adalah 1 dan 2. Data responden sebelum dilakukan senam kaki memiliki statistik menunjukan 95\% responden memiliki nilai rata- rata sensitivitas 1,67 dengan standar deviasi sensitivitas yang berada pada rentang 0,23 sampai 0,577. Hasil analiis data menunjukan pada kelompok dengan 3,10. sebelum dilakukan senam kaki memiliki nilai

Tabel 2. Sensitivitas Kaki Penderita Diabetes Mellitus Sesudah Dilakukan Senam Kaki Di Puskesmas Parungponteng Kecamatan Cibalong Kabupaten Tasikmalaya

\begin{tabular}{|c|c|c|c|c|c|c|}
\hline Variabel & & $\mathrm{N}$ & Mean & Standar Deviasi & Min - Max & $\mathrm{Cl} 95 \%$ \\
\hline $\begin{array}{l}\text { Sensitivitas } \\
\text { senam kaki }\end{array}$ & sesudah & 25 & 2,36 & 0,790 & $1-3$ & $2,01-2,71$ \\
\hline
\end{tabular}

Sumber: Data Penelitian, 2019

Berdasarkan tabel diketahui bahwa dari 25 orang sensitivitas terendah dan tertinggi adalah 1 dan 3. Data responden sesudah dilakukan senam kaki memiliki statistik menunjukan 95\% responden memiliki nilai rata- rata sensitivitas 2,36 dengan standar deviasi 0,790. Hasil analiis data menunjukan pada kelompok sensitivitas yang berada pada rentang 2,01 sampai dengan 2,71 .

sebelum dilakukan senam kaki memiliki nilai

Tabel 3. Pengaruh Senam Kaki Diabetik Terhadap Sensitivitas Kaki Penderita Diabetes Mellitus Di Puskesmas Parungponteng Kecamatan Cibalong Kabupaten Tasikmalaya

\begin{tabular}{|c|c|c|c|c|c|}
\hline Variabel & $\mathrm{N}$ & Mean & Standar Deviasi & Min -Max & P Value \\
\hline Nilai sensitivita & & & & & \\
\hline sebelum senam & 25 & 1,67 & 0,577 & $1-2$ & 0,001 \\
\hline
\end{tabular}

Sumber: Data Penelitian, 2019

Berdasarkan tabel diketahui bahwa dari 25 orang responden sebelum dilakukan senam kaki memiliki rata- rata sensitivitas 1,67 dengan standar deviasi 0,577. Hasil analiis data menunjukan pada kelompok sebelum dilakukan senam kaki memiliki nilai sensitivitas terendah dan tertinggi adalah 1 dan 3 . Berdasarkan uji statistik dengan menggunakan uji T di dapatkan $\mathrm{p}$ value sebesar 0,001 dengan tingkat 
kepercayaan 95\% dan alfa 0,05 maka dapat di simpulkan bahwa Ada pengaruh senam kaki diabetik terhadap sensitivitas kaki penderita diabetes mellitus

\section{PEMBAHASAN}

Berdasar hasil penelitian yang dilakukan pada pasien DM di Kabupaten Tasikmalaya menunjukkan adanya perbedaan selisih mean rata-rata sensitivitas kaki sebelum dengan sesudah intervensi pada kelompok intervensi lebih tinggi dibanding selisih mean rata-rata sensitivitas kaki sebelum dengan sesudah intervensi pada kelompok kontrol. Diketahui bahwa dari 25 orang responden sebelum dilakukan senam kaki memiliki rata- rata sensitivitas 4,84 dengan standar deviasi 1,434. Hasil analisis data menunjukan pada kelompok sebelum dilakukan senam kaki memiliki nilai sensitivitas terendah dan tertinggi adalah 2 dan 6 . Berdasarkan uji statistik dengan menggunakan uji Wilcoxon di dapatkan $p$ value sebesar 0,010 dengan tingkat kepercayaan 95\% dan alfa 0,05 maka dapat di simpulkan terdapat pengaruh senam kaki terhadap sensitivitas kaki pada penderita diabetes mellitus di puskesmas parungponteng kecamatan cibalong kabupaten Tasikmalaya

Penelitian ini sejalan dengan teori yang menyatakan bahwa senam kaki diabetik dapat membantu melancarkan dan memperbaiki sirkulasi darah pada kaki. Melalui gerakan pada senam kaki diabetik, otototot kaki akan berkontraksi sehingga akan meningkatkan sensitivitas sel terhadap glukosa darah sehingga glukosa darah yang kadarnya tinggi di dalam darah dapat terpakai oleh otot (Smeltzer \& Bare,

Selain mencegah komplikasi senam kaki juga dapat menurunkan kadar gula darah dalam tubuh pada lansia. Sesuai dengan penelitian Priyanto (2013) di Puskesmas Parungponteng Kecamatan Cibalong Kabupaten Tasikmalaya.

2002). Sirkulasi darah yang lancar akan membawa oksigen dan nutrisi menuju sel dan jaringan saraf yang akan mempengaruhi proses metabolisme sel Schwann, sehingga fungsi akson dapat baik kembali. Fungsi sel saraf yang optimal pada pasien DM akan mempertahankan fungsi sensitivitas kaki (Suriaoka, 2012).

Senam kaki merupakan metode untuk mencapai peningkatannya diperlukan waktu yang lama dan teratur serta harus dipraktekkan. Hal ini sesuai dengan penelitian Prima,. (2019) yang menyatakan bahwa ada peningkatan keterampilan secara signifikan setelah 6 bulan latihan. Oleh karena itu, senam kaki yang dilakukan secara teratur dan seimbang dapat berdampak positif bagi penderita DM. Seperti penelitian yang diungkapkan oleh Perkeni, 2006, perawatan kaki diabetisi yang teratur akan mencegah atau mengurangi terjadinya komplikasi kronik pada kaki. Beberapa penelitian terkait dengan sensitivitas pada pasien DM diantaranya seperti yang dilakukan oleh Suhertini \& Subandi, (2016) yang menyatakan terdapat perbedaan rata-rata nilai sensitivitas kaki dan pengkajian fisik kaki, sesudah senam kaki antara kelompok kontrol dengan kelompok intervensi. Sementara Sunaryo dan Sudiro, (2014) menjelaskan adanya pengaruh senam diabetik penurunan resiko ulkus kaki diabetic.

menemukan perbedaan selisih mean rata-rata kadar gula darah sebelum dengan sesudah intervensi pada kelompok intervensi lebih tinggi dibanding selisih mean rata-rata sensitivitas kaki sebelum dan sesudah 
intervensi pada kelompok kontrol. Hal ini menunjukan bahwa lansia yang diberikan intervensi atau perlakuan senam kaki relatif memiliki nilai kadar gula darah yang rendah darah. Nilai kadar gula darah yang rendah ini menggambarkan terjadinya perbaikan nilai kadar gula darah setelah dilakukan senam kaki. Penurunan kadar gula darah menunjukkan terjadinya penurunan tingkat gangguan diabetes, karena tingkat keparahan diabetes melitus lansia akan ditunjukkan dengan adanya kadar gula darah yang semakin tinggi, melebihi nilai ambang batas normal.

\section{KESIMPULAN}

Terdapat pengaruh yang signifikan antara senam kaki diabetik terhadap sensitivitas kaki pada penderita DM di Puskesmas Parungponteng Kecamatan Cibalong Kabupaten Tasikmalaya.

\section{DAFTAR PUSTAKA}

Badan Penelitian Dan Pengembangan Kesehatan. (2013). Riset Kesehatan Dasar. Jakarta: Kementrian Kesehatan RI

Dinas Kesehatan, (2019). Jumlah Penyakit DM Di Tasikmalaya International Diabetes

Federation(IDF) 2013, Prevalensi Penyakit DM di IndonesiaMuzahidin, Hartoyo, and Maria (2015) 'Pengaruh Terapi Pijat Repleksi Pada Telapak Kaki Terhadap Sensitivitas Kaki pada Penderita Diabetes Mellitus Tipe 2 di Puskesmas Karangayu Semarang” Jurnal Ilmu Keperawatan dan

Priyanto, S.(2013).Pengaruh Senam Kaki Terhadap Sensitivitas Kaki Dan Kadar Gula

Pada Aggregat Lansia Diabetes Melitus. Jurnal http://lib.ui.ac.id/file?file=digital/20300843
30470\%20\%20Penagruh\%20Senam.pdf. Diakses pada tanggal 2 Mei 2019

Perkeni (2011) Konsensus pengolahan dan pencegahan diabetes mellitus tipe $2 \mathrm{di}$

Prima, R. (2019). Pengaruh Senam Kaki Terhadap Peningkatan Sensitivitas Kaki Pada Penderita Diabetes Melitus Tipe II di Wilayah Kerja Puskesmas Tanjung Emas Kabupaten Tanah Datar.Jurnal Amanah Kesehatan, 1(2), 28-34.

Sunaryo dan Sudiro . (2014). Pengaruh Senam Diabetik Terhadap Penurunan Resiko Ulkus Kaki Diabetik pada paasien DM Tipe 2 di Perkumpulan Diabetik Surakarta : Kementrian Kesehatan Polteknik Surakarta Jurusan Keperawatan

Suhertini, C., \& Subandi, S. (2016). Senam Kaki Efektif Mengobati Neuropati Diabetik pada Penderita Diabetes Mellitus. Jurnal Kesehatan, 7(3), 480-487.

Suriaoka, (2012). Penyakit Degeneratif Yogyakarta ; Nuha Medika

Smeltzer,S.C.,\& Bare, B.G. 2002. Buku Ajar Keperawatan Medikal Bedah (Vol.2). Jakarta ; EGC Tjokroprawiro, A., (2007) Angiopati Diabetik ( Mikro dan Makro Angiopati Diabetik) Buku Ajar Ilmu Penyakit Dalam Jilid 1. Jakarta ; Balai Penerbit FKUI. Hal 601

Wahyuni, Aria. (2016) . Senam Kaki Diabetik Efektif Meningkatkan Angkle Brachial Indek Pasien Diabetes Mellitus Tipe 2. Junal ipteks Terapan 9.2 hal 19-27

Kebidanan 7.2 